\title{
KEPUASAN BERDASARKAN PERSEPSI DAN HARAPAN WALI MURID TK X DI KABUPATEN LUMAJANG
}

\author{
Noer Aisyah Barlian, SKM, MM \\ Program Studi Manajemen, STIE Widya Gama Lumajang \\ E-mail: berlian.0302@gmail.com
}

\begin{abstract}
This study aims to determine the perceptions and expectations of guardians of kindergarten $X$ on the satisfaction of guardians of TK $X$ students in Lumajang District. This research is expected to give description about perception and expectation of X kindergarten students and their satisfaction toward TK X in Lumajang Regency. This research prioritizes the variables of perception, expectation and satisfaction of guardian of pupil in TKX of Lumajang Regency. This research takes samples of all X TK students in Lumajang District. The research method is descriptive by using questionnaires distributed to QKX pupil in Lumajang District. The result of this research is the satisfaction of the student guardian in TKX of Lumajang Regency to the highest service quality in tangible dimension, and the expectation and the perception of the guardian of the students on the quality of service is very satisfied. Furthermore, this research is expected to contribute in the development of the study of management science, especially human resources management, so it can be a reference and development for further research.
\end{abstract}

\section{Keyword: Satisfaction, Perception, Expectation, Kindergarten}

Abstrak. Penelitian ini bertujuan untuk mengetahui persepsi dan harapan wali murid TK X terhadap kepuasan wali murid TK X di Kabupaten Lumajang. Penelitian ini diharapkan dapat memberikan gambaran mengenai persepsi dan harapan para wali murid TK X dan kepuasannya terhadap TK X di Kabupaten Lumajang. Penelitian ini memprioritaskan pada persepsi, harapan dan kepuasan wali murid di TK X Kabupaten Lumajang. Penelitian ini mengambil sampel seluruh wali murid TK X di Kabupaten Lumajang. Metode penelitian adalah deskriptif dengan menggunakan kuesioner yang dibagikan kepada wali murid TK X di Kabupaten Lumajang. Hasil penelitian ini yaitu kepuasan wali murid di TK X Kabupaten Lumajang terhadap kualitas layanan tertinggi pada dimensi emphaty, dan harapan serta persepsi wali murid terhadap kualitas layanan tergolong sangat puas. Selanjutnya penelitian ini diharapkan dapat memberikan kontribusi dalam pengembangan kajian ilmu manajemen khususnya manajemen sumber daya manusia, sehingga dapat menjadi acuan dan pengembangan untuk penelitian selanjutnya.

\section{Kata Kunci: Kepuasan, Persepsi, Harapan, Taman Kanak-Kanak PENDAHULUAN}

Lembaga pendidikan antar wilayah di Indonesia mengalami perkembangan yang berbeda-beda sesuai dengan tata kelola wilayah. Menurut UNICEF Indoensia bahwa kualitas pendidikan dasar dan menengah perlu diperhatikan di semua tingkat dan provinsi. Dari 65 negara yang dikaji oleh Program OECD untuk Pengkajian Siswa Internasional pada tahun 2009, Indonesia menduduki peringkat di antara 13 negara dalam kelompok terakhir untuk tiga kategori yang dikaji (membaca, matematika dan ilmu pengetahuan). Perkembangan secara fisik dan kualitas output yang dihasilkan oleh lembaga pendidikan merupakan aspek yang 
penting untuk dan sekaligus sebagai pendorong pemasaran dari sebuah lembaga pendidikan.

Menurut UNICEF Indonesia bahwa rendahnya kualitas pendidikan berawal dari proses belajar dan mengajar. Hanya 27 persen guru sekolah dasar yang memenuhi syarat. Proporsi ini meningkat sampai 76 dan 84 persen masing-masing di tingkat sekolah menengah pertama dan sekolah menengah atas. Upaya-upaya untuk meningkatkan kualifikasi guru dimulai pada tahun 2006 dengan sertifikasi guru pra-jabatan (in-service) dan guru dalam jabatan (in-service).. Akan tetapi, studi terakhir menunjukkan bahwa sertifikasi dan kualifikasi formal guru belum menimbulkan dampak terhadap kinerja siswa. Sertifikasi guru saja sepertinya tidak cukup untuk meningkatkan mutu pendidikan (Unicef Indonesia, 2012).

Berbeda dengan guru di lembaga pendidikan swasta, sistem reward guru dan perkembangan sekolahan secara fisik ditentukan oleh lembaga tersebut. Oleh karena itu, output pengajaran para lembaga diharapkan menghasilkan siswa yang berkualitas sehingga menjadi sebuah promosi mandiri untuk sebuah lembaga swasta. Peningkatan jumlah lembaga swasta dalam bidang pendidikan membuat kompetisi semakin ketat untuk menarik minat masyarakat dalam memilih lembaga pendidikan. Berbagai kegiatan untuk saling mempromosikan kegiatan sekolah diantara sekolahan sudah dilaksanakan oleh sekolahan, akan tetapi perlu diimbangi dengan kondisi fisik dan kualitas pelayanan untuk dapat tetap bertahan dalam persaingan antar lembaga pendidikan. Pendidikan usia dini dan taman kanak kanak merupakan salah satu proses awal dalam memenangkan kompetisi antar lembaga pendidikan swasta. Pendidikan usia dini dan taman kanak kanak yang bersinergi dengan sekolahan dasar, sekolah menengah pertama, dan sekolah menengah atas merupakan dimulainya untuk membidik siswa yang akan memilih untuk bersekolah di lembaga pendidikan swasta tersebut. Apabila kualitas dan layanan serta output sesuai dengan harapan wali murid maka wali murid akan meneruskan pendidikan kejenjang pendidikan selanjutnya dilembaga tersebut.

Menurut Engel dkk (1994) bahwa kepuasan konsumen merupakan evaluasi yang terjadi pascakonsumsi bahwa sesuatu alternative yang dipilih setidaknya memenuhi atau melebihi harapan. Penilaian memenuhi atau tidak memenuhi standar kepuasan konsumen tergantung dari pascakonsumsi. Persepsi sebagai proses menggabungkan dan mengorganisasikan data data indra kita untuk dikembangkan sedemikian rupa sehingga kita dapat menyadari lingkungan disekeliling kita termasuk sadar akan diri kita sendiri (Saleh, 2002). Menurut Hill (1992) harapan adalah, apa yang konsumen pikirkan harus disediakan oleh penyedia jasa. Akan tetapi, harapan bukan merupakan prediksi dari apa yang akan disediakan oleh penyedia jasa.

Depdikbud (2003) pendidikan anak usia dini adalah upaya pembinaan yang di tunjukan kepada anak sejak lahir sampai dengan usia 6 tahun yang di lakukan melalui pemberian rangsangan pendidikan untuk membantu pertumbuhan dan perkembangan jasmani dan rohani agar anak memiliki kesiapan dalam memasuki pendidikan lebih lanjut. Taman kanak-kanak adalah salah satu bentuk satuan pendidikan anak usia dini pada jalur pendidikan formal yang menyelenggakan pendidikan empat sampai enam tahun. Pendidikan anak usia dini pada jalur pendidikan formal ,nonformal berbentuk taman kanak-kanak (TK), taman penitipan anak (TPA), kelompok bermain (KB), raudatul athfal (RA), dan ketentuan-ketentuan mengenai pendidikan anak usia dini. Maka pendidikan usia dini merupakan cikal bakal generasi yang memiliki kualitas yang diharapkan oleh pendudukan jenjang yang lebih tinggi.

Penelitian Sukoco dan Sengguruh Nilowardono (2009) mengenai analisa harapan dan persepsi pelanggan PT PLN bahwa pelanggan PLN belum merasa puas 
atas pelayanan Service Quality yang diberikan oleh PT. PLN (PERSERO) APJ Surabaya Utara. Penelitian Iqbal (2008) yang meneliti tentang pengaruh persepsi nilai, harapan dan kepercayaan terhadap kepuasan pelanggan dihasilkan variabel persepsi nilai dan kepercayaan memengaruhi kepuasan akan PJI secara langsung dan signifikan. Sedangkan untuk variabel harapan mempunyai pengaruh yang negatif terhadap kepuasan konsumen. Hal ini membuktikan bahwa persepsi dan harapan menghasilkan pengaruh yang berbeda dan bahkan bisa selaras, oleh karena itu persepsi dan aharapan masyarakat terhadap lembaga pendidikan swasta patut untuk diketahui guna meningkatkan kualitas pendidikan di lembaga swasta.

Keberlangsungan jumlah peserta didik ditentukan dari tingkat sekolahan paling awal yaitu PAUD dan TK sehingga wali murid diharapkan memiliki kepuasan dan loyalitas sehingga dapat meneruskan proses pembelajaran sampai SMP di lembaga pendidikan tersebut. Peningkatan jumlah PAUD di Kabupaten Lumajang yang membuat angka masuk anak usia dini tersebar disetiap sekolahan. Hal ini selaras dengan penyataan Bunda PAUD Hj.Tutuk As at Malik yang menyampaikan bahwa pendidikan PAUD saat ini mengalami peningkatan dari tahun ke tahun, dengan bertambahnya jumlah satuan pendidikan yang merata di setiap wilayah di Kabupaten Lumajang (harianbhirawa, 2017). Oleh karena itu lembaga pendidikan swasta X perlu melakukan kajian kembali untuk menghadapi persaingan pada lini pendidikan anak usia dini untuk dapat tertarik masuk ke lembaga pendidikan tersebut. Maka dibutuhkan peninjauan kembali pada fasilitas dan pelayanan pada lini Taman Kanak Kanak agar mampu menarik minat orang tua.

Melihat fenomena TK X di Kabupaten Lumajang dan hasil penelitianpenelitian sebelumnya, bahwa dibutuhkan peninjauan lagi pada fasilitas dan pelayanan di lini Taman Kanak Kanak. Berdasarkan permasalahan tersebut, maka rumusan masalah pada penelitian ini yaitu:

a. Bagaimana kepuasan wali murid terhadap kualitas layanan secara umum TK X di Kabupaten Lumajang?

b. Bagaimana harapan dan persepsi terhadap dimensi tangible kualitas layanan TK X di Kabupaten Lumajang?

c. Bagaimana harapan dan persepsi terhadap dimensi kehandalan (reability) kualitas layanan TK X di Kabupaten Lumajang?

d. Bagaimana harapan dan persepsi terhadap dimensi daya tanggap (responsiveness) kualitas layanan TK X di Kabupaten Lumajang?

e. Bagaimana harapan dan persepsi terhadap dimensi jaminan (assurance) kualitas layanan TK X di Kabupaten Lumajang?

f. Bagaimana harapan dan persepsi terhadap dimensi emphati (emphaty) kualitas layanan TK X di Kabupaten Lumajang?

Penelitian ini bertujuan untuk mengetahui kepuasan wali murid terhadap persepsi dan harapan terhadap kualitas pelayanan yang diberikan oleh TK X Kabupaten Lumajang.

\section{KAJIAN TEORI}

\section{Kualitas Pelayanan}

Menurut Parasuraman et al dalam Unzicker (1999) bahwa kualitas layanan adalah konstruk sulit dipahami dan tidak jelas, disebabkan oleh karakteristik unik dari intangibility, ketidakterpisahan, variabilitas dan tidak tahan lama, Lee (Unzicker,1999). Kualitas pelayanan merupakan persepsi keseluruhan kinerja pelayanan perusahaan (Unzicker,1999).

Menurut Parasuraman (1988) kualitas pelayanan memiliki 5 dimensi, yaitu sebagai berikut: 
a. Tangibles (Fisik), adalah fasilitas fisik, peralatan, penampilan karyawan dalam melayani konsumen. Tangibles merupakan bukti nyata dari kepedulian dan perhatian yang diberikan oleh penyedia jasa kepada konsumen. Pentingnya dimensi tangibles ini akan menumbuhkan image penyedia jasa terutama bagi konsumen baru dalam mengevaluasi kualitas jasa. Perusahaan yang tidak memperhatikan fasilitas fisiknya akan menumbuhkan kebingungan atau bahkan merusak image perusahaan.

b. Reliability (Keandalan), adalah kemampuan perusahaan untuk memberikan pelayanan yang benar, tepat waktu dan dapat diandal-kan. Reliability atau keandalan merupakan kemampuan perusahaan untuk melaksanakan jasa sesuai dengan apa yang telah dijanjikan secara tepat waktu. Pentingnya dimensi ini adalah kepuasan konsumen akan menurun bila jasa yang diberikan tidak sesuai dengan yang dijanjikan. Jadi komponen atau unsur dimensi reliability ini merupakan kemampuan perusahaan dalam menyampaikan jasa secara tepat dan pembebanan biaya secara tepat.

c. Responsiveness (Perhatian), adalah kesediaan untuk membantu para konsumen dan memberikan pelayanan yang cepat. Responsiveness atau daya tanggap merupakan kemampuan perusahaan yang dilakukan langsung oleh karyawan untuk memberikan pelayanan dengan cepat dan tanggap. Daya tanggap dapat menumbuhkan persepsi yang positif terhadap kualitas jasa yang diberikan. Termasuk didalamnya jika terjadi kegagalan atau keterlambatan dalam penyampaian jasa, pihak penyedia jasa berusaha memperbaiki atau meminimalkan kerugian konsumen dengan segera. Dimensi ini menekankan pada perhatian dan kecepatan karyawan yang terlibat untuk menanggapi permintaan, pertanyaan, dan keluhan konsumen. Jadi komponen atau unsur dari dimensi ini terdiri dari kesigapan karyawan dalam melayani konsumen, 45 kecepatan karyawan dalam melayani konsumen, dan penanganan keluhan konsumen

d. Assurance (Jaminan), adalah kesediaan dan kesiapan karyawan untuk memberikan pelayanan. Assurance atau jaminan merupakan pengetahuan dan perilaku employee untuk membangun kepercayaan dan keyakinan pada diri konsumen dalam mengkonsumsi jasa yang ditawarkan. Dimensi ini sangat penting karena melibatkan persepsi konsumen terhadap resiko tidak pasti yang tinggi terhadap kemampuan penyedia jasa. Perusahaan membangun kepercayaan dan kesetiaan konsumen melalui karyawan yang terlibat langsung menangani konsumen. Jadi komponen dari dimensi ini terdiri dari kompetensi karyawan yang meliputi keterampilan, pengetahuan yang dimiliki karyawan untuk melakukan pelayanan dan kredibilitas perusahaan yang meliputi hal-hal yang berhubungan dengan kepercayaan konsumen kepada perusahaan seperti, reputasi perusahaan, prestasi dan lain-lain.

e. Emphaty (Empati), adalah rasa peduli, perhatian secara pribadi yang diberikan kepada konsumen. Emphaty merupakan kemampuan perusahaan yang dilakukan langsung oleh karyawan untuk memberikan perhatian kepada konsumen secara individu, termasuk juga kepekaan akan kebutuhan konsumen. Jadi komponen dari dimensi ini merupakan gabungan dari akses (access) yaitu kemudahan untuk memanfaatkan jasa yang ditawarkan oleh perusahaan, komunikasi merupakan kemampuan melakukan untuk menyampaikan informasi kepada konsumen atau memperoleh masukan dari konsumen dan pemahaman merupakan usaha untuk mengetahui dan memahami kebutuhan dan keinginan konsumen. 


\section{Persepsi}

Menurut Saleh (2002), bahwa persepsi sebagai proses menggabungkan dan mengorganisasikan data data indra kita untuk dikembangkan sedemikian rupa sehingga kita dapat menyadari lingkungan disekeliling kita termasuk sadar akan diri kita sendiri.

Menurut Shaleh dan Wahab (2004) karena persepsi lebih bersifat psikologis daripada merupakan proses penginderaan saja, maka ada beberapa faktor yang mempengaruhi:

a. Perhatian yang selektif

Dalam kehidupan manusia setiap saat akan menerima banyak sekali rangsangan dari lingkungannya. Meskipun demikian tidak berarti harus menanggapi semua rangsangan yang diterimanya untuk itu, individu memustakan perhatianya pada rangsangan-rangsangan tertentu rangsangan tertentu saja dengan demikian objek-objek atau gejala lain tidak akan tampil kemuka sebagai objek pengamatan.

b. Ciri- ciri rangsangan

Rangsangan yang bergerak di antara rangsangan yang diam akan lebih menarik perhatian. Demikian juga ra ngsangan yang paling besar diantara yang keci; yang kontras dengan latar belakangnya dan intensitas rangsangannya paling kuat.

c. Nilai dan kebutuhan individu

Seorang seniman tentu mempunyai pola dan cita rasa yang berbeda dalam pengamatannya di bandingkan seseorang yang bukan seniman, atau seorang anak dari glongan ekonomi rendah melihat koin lebih lebih besar daripada anak-anak orang kaya.

d. Pengalaman terdahulu

Pengalaman-pengalaman terdahulu sangat mempengaruhi bagaimana seseorang mempersepsi dunianya. Setelah manusia penginderaannya itu dan timbullah makna tentang objek itu pada diri manusia yang bersangkutan yang dinamai persepsi. Persepsi ini selanjutnya menimbulkan reaksi yang sesuai dengan reflex (Bell 1989 dalam Shaleh \& Wahab 2004).

\section{Harapan}

Menurut Hill (1992) harapan adalah, apa yang konsumen pikirkan harus disediakan oleh penyedia jasa. Akan tetapi, harapan bukan merupakan prediksi dari apa yang akan disediakan oleh penyedia jasa.

Menurut Horovitz (2000:8) dalam Sukoco dan Sengguruh (2009), harapan konsumen dapat terbentuk oleh empat faktor, antara lain :

a. Kebutuhan

Setiap konsumen yang memiliki kebutuhan selalu berharap agar kebutuhannya dapat dipenuhi oleh produsen sebagai penyedia barang dan jasa. Oleh karena itu produsen harus mengetahui kebutuhan konsumen dengan memberikan pelayanan yang terbaik sehingga harapannya dapat tercapai.

b. Media massa

Media adalah sarana promosi yang digunakan maskapai penerbangan untuk bersaing menarik perhatian konsumen dengan memberikan janji-janji pada konsumen. Janji-janji tersebut akan menimbulkan harapan pada konsumen.

c. Pengalaman masa lalu

Jika seorang konsumen pernah menikmati layanan yang memuaskan di suatu tempat, maka bila lain kali menggunakan layanan yang sama lagi maka konsumen akan mengharapkan pelayanan yang sama seperti yang pernah dialami. 
d. Mulut ke mulut (word of mouth)

Bila seorang konsumen yang tidak puas pada pelayanan yang diberikan, konsumen akan menceritakan pengalaman buruknya pada teman atau relasinya sehingga teman atau relasi dari konsumen itu tidak akan berharap banyak dari pelayanan yang disajikan atau dengan kata lain tidak akan mencoba menggunakan pelayanan tersebut nantinya. Sebaliknya, bila konsumen sudah merasa puas akan pelayanan yang diberikan, maka mereka akan menceritakan pengalamannya tersebut kepada teman atau relasinya sehingga teman atau relasi ini akan menggunakan pelayanan tersebut dan berharap mendapat pengalaman yang menyenangkan juga.

\section{Kepuasan Konsumen}

Menurut Engel dkk (1994) mendefinisikan kepuasan konsumen sebagai evaluasi pascakonsumsi bahwa sesatu alternative yang dipilih setidaknya memenuhi atau melebihi harapan. Penilaian memenuhi atau tidak memenuhi standar kepuasan konsumen tergantung dari pascakonsumsi. Kotler (2002) menjelaskan bahwa kepuasan konsumen adalah tingkat perasaan seseorang setelah membandingkan kinerja (atau hasil) yang dirasakan dibandingkan dengan harapannya.

Aspek kepuasan konsumen, menurut Kotler (2002) mengemukakan pendapat tentang aspek - aspek kepuasan konsumen, meliputi
a. Expectation (harapan)
Hal yang mempengaruhi kepuasan konsumen diawali pada tahap sebelum pembelian, yaitu ketika konsumen menyusun harapan tentang apa yang akan diterima dari produk atau produk.

b. Perfomance (kinerja)

Selama kegiatan konsumsi, konsumen merasakan kinerja dan manfaat dari produk secara aktual dilihat dari dimensi kepentingan konsumen.

c. Comparisme (kesesuaian)

Setelah mengkonsumsi, baik harapan sebelum pembelian dan persepsi kinerja actual dibandingkan oleh konsumen.

d. Confirmation atau Disconfirmation (penegasan)

Penegasan dari harapan konsumen, apakah harapan pra-pembelian dengan persepsi pembelian sama atau tidak.

e. Discrepancy (ketidak-sesuaian)

Jika tingkat kinerja tidak sama, pengakuan ketidak-samaan menentukan perbedaan satu sama lain. Diskonfirmasi yang negatif menentukan kinerja yang actual ada dibawah tingkat harapan maka semakin besar ketidak-puasan konsumen

\section{METODE PENELITIAN}

Jenis penelitian ini menurut tingkat eksplanasi (penjelasan) adalah penelitian yang bermaksud menjelaskan kepuasan berdasarkan persepsi dan harapan wali murid TK X Kabupaten Lumajang. Maka jenis penelitian pada penelitian ini yaitu penelitian eksplanatori yaitu penelitian yang dilakukan untuk menjelaskan kepuasan pelanggan berdasarkan persepsi dan harapan pelanggan. Pada penelitian ini menjelaskan tentang faktor kualitas pelayanan TK X Kabupaten Lumajang yang mendapatkan perhatian tinggi dari wali murid serta gambaran persepsi dan harapan terhadap kualitas pelayanan di TK X Kabupaten Lumajang.

\section{Metode dan Teknik}

Metode penelitian ini menggunakan metode deskriptif, yaitu metode-metode penelitian yang memusatkan perhatian pada masalah-masalah atau fenomena yang 
bersifat aktual pada saat penelitian dilakukan, kemudian menggambarkan faktafakta tentang masalah yang diselidiki sebagaimana adanya diiringi dengan interprestasi yang rasional dan akurat (Nawawi,2003) Maka penelitian ini akan menggambarkan fakta-fakta dan menjelaskan keadaan dari objek penelitian berdasarkan fakta-fakta dan mencoba menganalisis kebenarannya berdasarkan data yang diperoleh.

Teknik pengumpulan data adalah dengan menggunakan kuesioner atau daftar pernyataan yang dikirimkan kepada responden. Pengukuran data dilakukan dengan memberi skor pada tiap-tiap jawaban dari butir pertanyaan dari kuesioner. Pemberian skor dalam penelitian ini berdasarkan skala likert.

Untuk skor jawaban Sangat puas dinilai 5

Untuk skor jawaban Puas dinilai 4

Untuk skor jawaban Cukup dinilai 3

Untuk skor jawaban Tidak puas dinilai 2

Untuk skor jawaban Sangat tidak puas dinilai 1

Setelah mendapatkan hasil berupa prosentase, hasilnya dapat ditafsirkan dengan kalimat yang bersifat kualitatif sebagai berikut:

$\begin{array}{ll}\text { Sangat Puas } & =81-100 \% \\ \text { Puas } & =61-80 \% \\ \text { Cukup } & =41-60 \% \\ \text { Tidak Puas } & =21-40 \% \\ \text { Sangat Tidak Puas } & =0-20 \%\end{array}$

\section{Proses Pengumpulan Data}

Penelitian ini dilakukan terhadap wali murid TK X di Kabupaten Lumajang. Alasan dipilihnya TK X Kabupaten Lumajang adalah merupakan TK X yang dibawah naungan yayasan yang bergerak dibidang pendidikan dari Pendidikan Usia Dini, Taman Kanak-kanak, Sekolah Dasar hingga Sekolah Menengah Pertama. Sebanyak 93 responden diberikan kuesioner untuk menjaring pendapat mereka atas kepuasan wali murid berdasarkan persepsi dan harapan wali murid. Berdasarkan pendapat responden ini maka dapat diketahui mengenai kepuasan wali murid tertinggi terhadap kualitas layanan serta persepsi dan harapan wali murid terhadap kualitas layanan di TK X Kabupaten Lumajang.

\section{HASIL DAN PEMBAHASAN}

\section{Hasil Penelitian}

a. Deskripsi Responden

Adapun deskripsi respoden menurut Usia, Jenis Kelamin, Tingkat Pendidikan dan Pekerjaan pada penelitian ini dijelaskan pada tabel berikut:

Tabel 1.1 Deskripsi Responden Menurut Usia dan Jenis Kelamin Wali Murid di TK A Kabupaten Lumajang

\begin{tabular}{|c|c|c|c|}
\hline \multirow[t]{2}{*}{ Usia } & \multicolumn{2}{|c|}{ Jenis Kelamin } & \multirow[t]{2}{*}{ Total } \\
\hline & Laki-Laki & Perempuan & \\
\hline 3 & 0 & 1 & 1 \\
\hline 4 & 0 & 1 & 1 \\
\hline 6 & 0 & 1 & 1 \\
\hline
\end{tabular}




\begin{tabular}{|c|c|c|c|}
\hline 7 & 0 & 1 & 1 \\
\hline 9 & 0 & 3 & 3 \\
\hline 0 & 1 & 3 & 4 \\
\hline 1 & 0 & 4 & 4 \\
\hline 2 & 2 & 4 & 6 \\
\hline 3 & 0 & 2 & 2 \\
\hline 4 & 2 & 2 & 4 \\
\hline 5 & 1 & 6 & 7 \\
\hline 6 & 0 & 4 & 4 \\
\hline 7 & 0 & 3 & 3 \\
\hline 8 & 0 & 4 & 4 \\
\hline 9 & 0 & 4 & 4 \\
\hline 0 & 0 & 1 & 1 \\
\hline 2 & 1 & 3 & 4 \\
\hline 3 & 0 & 2 & 2 \\
\hline 0 & 0 & 1 & 1 \\
\hline & 7 & 50 & 57 \\
\hline
\end{tabular}

Sumber: Hasil Pengolahan Data Tahun 2017

Responden yang memberikan identitas lengkap dalam pengisian kuesioner adalah sebanyak 57 wali murid, sisanya sebanyak 36 wali murid tidak memberikan identitas lengkap sehingga dikeluarkan dari rekapitulasi identitas wali murid. Wali murid TK X Kabupaten Lumajang yang terbanyak dalam berpartisipasi pada pengisian kuesioner yaitu berjenis kelamin perempuan dan yang terbanyak pada usia 37 tahun. Wali murid berjenis kelamin perempuan yang termuda pada usia 23 tahun dan yang tertua pada usia 60 tahun. Pada wali murid berjenis kelamin lakilaki yang berpartisipasi dalam pengisian kuesioner yaitu yang termuda pada usia 30 tahun dan yang tertua pada usia 42 tahun

b. Deskripsi Harapan dan Persepsi Wali Murid TK X Kabupaten Lumajang 
Tabel 1.2 Deskripsi Harapan dan Persepsi Wali Murid TK X

Kabupaten Lumajang

\begin{tabular}{|c|c|c|}
\hline \multicolumn{3}{|r|}{ 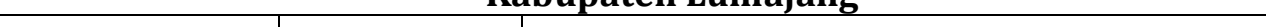 } \\
\hline Keterangan & Prosentase & $\begin{array}{l}\text { Kepuasan Terhadap Kualitas Layanan } \\
\text { (Persepsi dibandingkan harapan) }\end{array}$ \\
\hline Persepsi & $81,54 \%$ & \multirow{3}{*}{$\begin{array}{c}94,81 \% \\
\text { (Sangat Puas) }\end{array}$} \\
\hline Harapan & $86 \%$ & \\
\hline Gap/Selisih & $4,46 \%$ & \\
\hline
\end{tabular}

Sumber: Hasil Pengolahan Data Tahun 2017

Hasil olah data kuesioner didapatkan harapan wali murid TK X Kabupaten Lumajang sebesar $86 \%$ dan persepsi wali murid sebesar $81,54 \%$. Gap atau selisih harapan dan persepsi wali murid TK A terhadap kualitas layanan sebesar 4,46\%.

Tabel 1.3 Deskripsi Harapan dan Persepsi Terhadap Dimensi Tangible

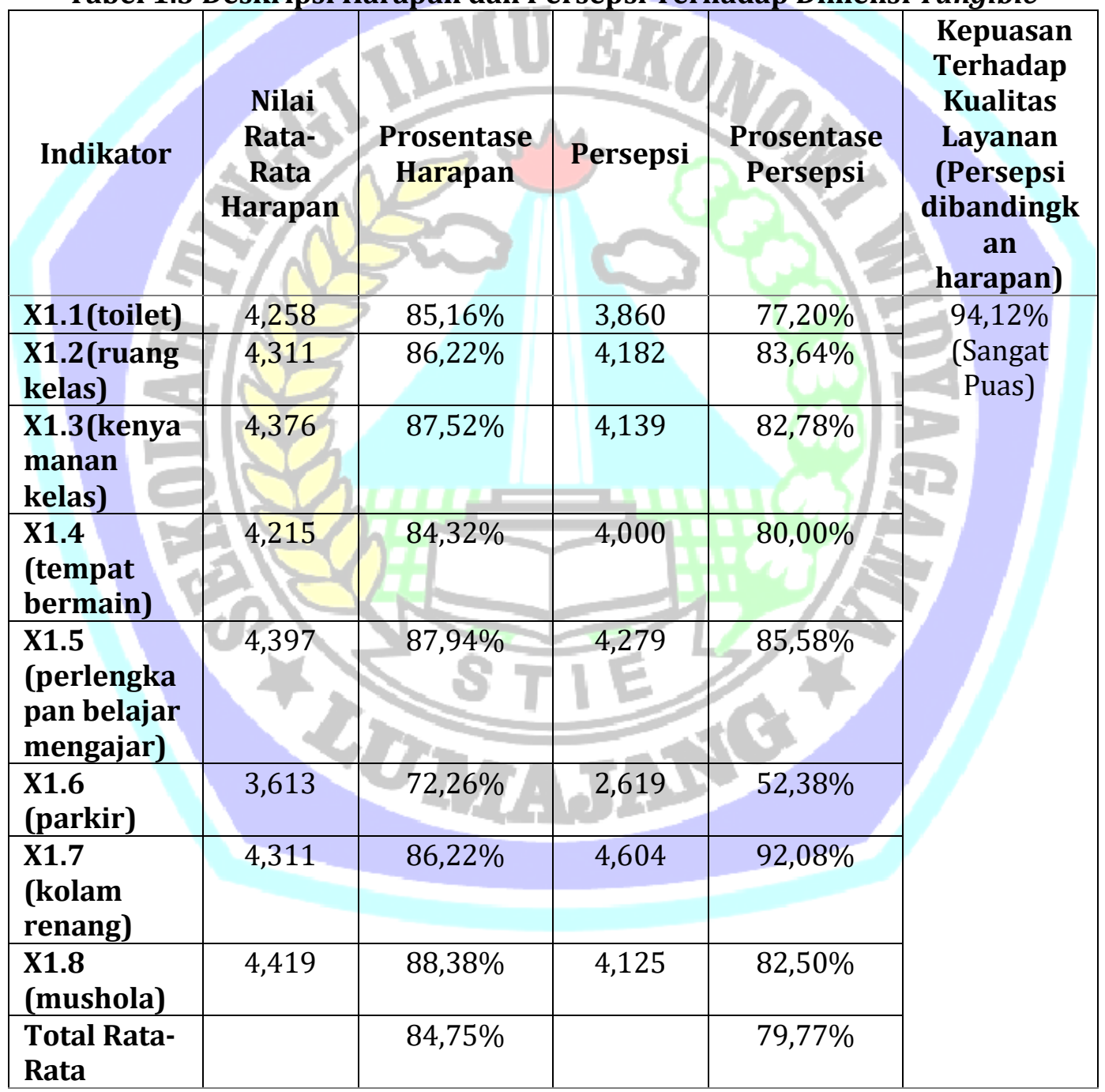

Sumber: Hasil Pengolahan Data Tahun 2017

Harapan wali murid TK A pada dimensi tangible sebesar 84,75\% dan persepsi wali murid TK A pada dimensi tangible sebesar sebesar 79,77\%. Pada prosentase harapan wali murid terbesar pada indikator mushola sebesar $88,38 \%$ dan pada prosentase persepsi pada variabel kolam renang sebesar 92,08\%. 
Tabel 1.4 Deskripsi Harapan dan Persepsi Terhadap Dimensi Reability

\begin{tabular}{|l|c|c|c|c|c|}
\hline \multicolumn{1}{|c|}{ Indikator } & $\begin{array}{c}\text { Nilai } \\
\text { Rata- } \\
\text { Rata } \\
\text { Harapan }\end{array}$ & $\begin{array}{c}\text { Prosentase } \\
\text { Harapan }\end{array}$ & $\begin{array}{c}\text { Nilai } \\
\text { Rata- } \\
\text { Rata } \\
\text { Persepsi }\end{array}$ & $\begin{array}{c}\text { Prosentase } \\
\text { Persepsi }\end{array}$ & $\begin{array}{c}\text { Kepuasan } \\
\text { Terhadap } \\
\text { Kualitas } \\
\text { Layanan } \\
\text { (Persepsi } \\
\text { dibandingk } \\
\text { an }\end{array}$ \\
harapan)
\end{tabular}

Sumber: Hasil Pengolahan Data Tahun 2017

Prosentase harapan wali murid terhadap dimensi kehadalan pada kualitas pelayanan TK X Kabupaten Lumajang sebesar 85,745\%. Prosentase persepsi wali murid terhadap dimensi kehandalan pada kualitas pelayanan TK X Kabupaten Lumajang sebesar $80,94 \%$.

Tabel 1.5 Deskripsi Harapan dan Persepsi Terhadap Dimensi Responsiveness

\begin{tabular}{|l|c|c|c|c|c|}
\hline Indikator & $\begin{array}{c}\text { Nilai } \\
\text { Rata- } \\
\text { rata } \\
\text { Harapan }\end{array}$ & $\begin{array}{c}\text { Prosentase } \\
\text { Harapan }\end{array}$ & $\begin{array}{c}\text { Nilai } \\
\text { Rata- } \\
\text { rata } \\
\text { Persepsi }\end{array}$ & $\begin{array}{c}\text { Prosentase } \\
\text { Persepsi }\end{array}$ & $\begin{array}{c}\text { Kepuasan } \\
\text { Terhadap } \\
\text { Kualitas } \\
\text { Layanan } \\
\text { (Persepsi } \\
\text { dibandingkan } \\
\text { harapan) }\end{array}$ \\
\hline $\begin{array}{l}\text { X3.1(daya } \\
\text { tanggap } \\
\text { terhadap } \\
\text { keluhan) }\end{array}$ & 4,27 & $85,4 \%$ & 4,11 & $82,2 \%$ & $\begin{array}{c}95,54 \% \\
\text { (Sangat Puas) }\end{array}$ \\
\hline X3.2(daya & 4,23 & $84,6 \%$ & 4,08 & $80,00 \%$ & \\
\hline
\end{tabular}




\begin{tabular}{|l|l|l|l|l|}
\hline $\begin{array}{l}\text { tanggap } \\
\text { dalam } \\
\text { memberikan } \\
\text { informasi) }\end{array}$ & & & & \\
\cline { 1 - 4 } Total Rata & & $85 \%$ & & $81,1 \%$ \\
\hline
\end{tabular}

Sumber: Hasil Pengolahan Data Tahun 2017

Rata-rata prosentase harapan dimensi responsiveness wali murid TK X sebesar 85\% dan rata-rata prosentase persepsi dimensi responsiveness wali murid TK X sebesar 81,1\%. Pada indikator dimensi responsiveness yang memiliki nilai prosentase harapan dan persepsi yang tertinggi pada variable daya tanggap terhadap keluhan

Tabel 1.6 Deskripsi Harapan dan Persepsi Terhadap Dimensi Assurance

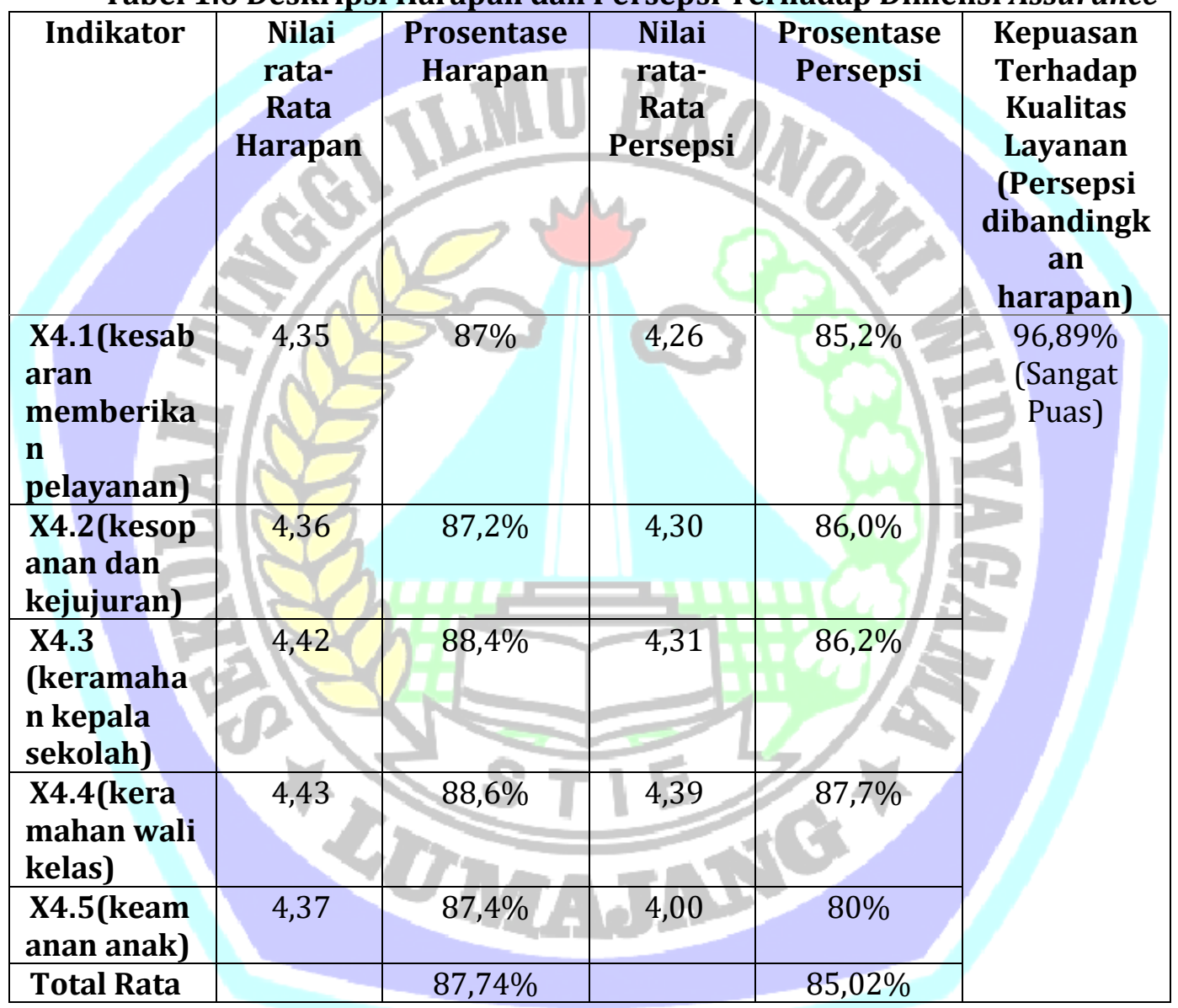

Sumber: Hasil Pengolahan Data Tahun 2017

Dimensi assurance pada kualitas layanan TK X Kabupaten Lumajang yaitu harapan wali murid TK X Kabupaten Lumajang lebih tinggi $87,74 \%$ daripada persepsi wali murid TK X Kabupaten Lumajang sebesar 85,02\%. Semua indikator pada variabel pada dimensi assurance memiliki nilai harapan lebih tinggi daripada persepsi wali murid TK X Kabupaten Lumajang. 
Tabel 1.7 Deskripsi Harapan dan Persepsi Terhadap Dimensi Emphaty

\begin{tabular}{|c|c|c|c|c|c|}
\hline Indikator & $\begin{array}{c}\text { Nilai } \\
\text { Rata- } \\
\text { Rata } \\
\text { Harapan }\end{array}$ & $\begin{array}{c}\text { Prosentase } \\
\text { Harapan }\end{array}$ & $\begin{array}{c}\text { Nilai } \\
\text { Rata- } \\
\text { Rata } \\
\text { Persepsi }\end{array}$ & $\begin{array}{c}\text { Prosentase } \\
\text { Persepsi }\end{array}$ & $\begin{array}{c}\text { Kepuasan } \\
\text { Terhadap } \\
\text { Kualitas } \\
\text { Layanan } \\
\text { (Persepsi } \\
\text { dibandingka } \\
\text { n harapan) }\end{array}$ \\
\hline $\begin{array}{l}\text { X5.1(perh } \\
\text { atian } \\
\text { terhadap } \\
\text { keluhan) }\end{array}$ & 4,33 & $86,6 \%$ & 4,08 & $81,6 \%$ & $\begin{array}{c}95,74 \% \\
\text { (Sangat puas) }\end{array}$ \\
\hline $\begin{array}{l}X 5.2 \text { (sika } \\
\text { p adil) }\end{array}$ & 4,30 & $86 \%$ & 4,13 & $82,6 \%$ & \\
\hline $\begin{array}{l}\text { X5.3(sika } \\
\text { p sabar) }\end{array}$ & 4,43 & & & & \\
\hline $\begin{array}{l}\text { X5.4 } \\
\text { (pengertia } \\
\text { n } \\
\text { terhadap } \\
\text { kebutuha } \\
\text { n khusus) }\end{array}$ & & & 4,11 & & \\
\hline Total Rata & ( & $86,95 \%$ & & $83,25 \%$ & a \\
\hline
\end{tabular}

Sumber: Data di Olah (2017)

Prosentase harapan wali murid TK X terhadap dimensi empati sebesar 86,95\% lebih tinggi dibanding prosentase persepsi wali murid TK X sebesar 83,25\%. Prosentase harapan pada setiap indikator dimensi empati lebih tinggi daripada prosentase persepsi indikator dimensi empati.

\section{HASIL DAN PEMBAHASAN}

Berdasarkan hasil penelitian, gambaran harapan dan persepsi wali murid TK $\mathrm{X}$ terhadap kualitas layanan pendidikan di TK X, harapan wali murid lebih tinggi daripada persepsi wali murid. Dimensi tangible merupakan gambaran fasilitas fisik yang disajikan oleh perusahaan untuk melayani konsumen seperti peralatan, bangunan, dan penamilan karyawan. Hal ini penting untuk konsumen karena dimensi tangible merupakan salah satu dimensi kualitas layanan yang mudah untuk di nilai. Harapan pada dimensi tangible merupakan keinginan wali murid TK X terhadap penyedia layanan pendidikan mengenai ketersediaan toilet, ruang kelas, kenyamanan kelas, perlangkapan belajar mengajar, parkir, kolam renang dan mushola yang nanti dapat dinikmati oleh peserta didik dan wali murid.

Salah satu bentuk indikator pada variabel reability adalah kemampuan petugas memberikan konseling, yaitu petugas atau guru/ustadzah yang mendampingi anak peserta didik dapat berkomunikasi dengan baik kepada wali murid dan anak peserta didik untuk memberikan solusi-solusi masalah pembelajaran dan pendampingan terhadap anak peserta didik. Pada indikator kemampuan konseling yang dimiliki oleh petugas atau guru/ustadzah, mendapatkan pandangan yang bagus dari wali murid meskipun masih dibawah keinginan wali murid. Wali murid merasa melalui fasilitas pelayanan petugas dalam bidang konselimg maka wali murid terpenuhi dalam hal informasi perkembangan anak dan solusi untuk mengatasi masalah-masalah yang berkaitan dengan anak dan proses 
belajar mengajar sehingga harapan wali murid terhadap ketangkasan petugas atau guru/ustdzah dalam indikator ini dapat ditingkatkan.

Pada dimensi responsiveness yang terdiri dari indikator daya tangga terhadap keluhan dan daya tanggap dalam memberikan informasi masih dirasa kurang dari harapan wali murid. Oleh karena itu diperlukan perhatian terhadap cara berkomunikasi dan merespon hal-hal secara sigap dan memberikan perhatian terhadap pelaksanaan dan pemberian solusi kepada wali murid. Maka secara keseluruhan, bahwa kepuasan wali murid terhadap kualitas layanan TK X pada dimensi responsivennes adalah sangat puas.

Dimensi assurance pada variabel kualitas pelayanan masih dinilai belum memenuhi harapan wali murid, sehingga dibutuhkan pembenahan dan juga pembaharuan terhadap fasilitas yang lebih terbaru, aman dan sesuai dengan peraturan yang terbaru. Selain itu diperhatikan prosesk rekruitmen tenaga pengajar supaya mendapatkan tenaga pengajar yang memenuhi kriteria dimensi assurance yang dapat meningkatkan kualitas pelayanan dan kepuasan pelanggan. Maka secara keseluruhan, bahwa kepuasan wali murid terhadap kualitas layanan TK X pada dimensi assurance adalah sangat puas.

Pada kualitas layanan TK X di Kabupaten Lumajang masih dibawah harapan wali murid TK X. Pada indikator perhatian terhadap keluhan, sikap adil, sabar dan pengertian terhadap kebutuhan khusus masih dinilai bahwa persepsi yang diterima masih belum dapat memenuhi keinginan wali murid TK X. Hal ini menunjukkan bahwa persepsi wali murid TK X terhadap perhatian terhadap keluhan, sikap adil, sikap sabar dan pengertian terhadap kebutuhan khusus dinilai kurang optimal karena terjadi gap yang tidak terlalu jauh rentangnya dengan harapan wali murid. Oleh karena itu, kedekatan wali murid dan petugas atau guru/ustadzah perlu ditingkatkan supaya petugas atau guru/ustadzah paham dan mengerti kondisi wali murid dan peserta didik.

\section{PENUTUP}

\section{Simpulan}

Adapun kesimpulan pada penelitian 'Kepuasan Berdasarkan Harapan dan Persepsi Wali Murid TK X di Kabupaten Lumajang' berdasarkan hasil pengujian, yaitu:

a. Kepuasan wali murid terhadap kualitas layanan secara umum TK X di Kabupaten Lumajang dinilai sangat puas dan nilai tertinggi pada dimensi emphaty.

b. Harapan dan persepsi terhadap dimensi tangible kualitas layanan TK X di Kabupaten Lumajang dinilai sangat puas.

c. Harapan dan persepsi terhadap dimensi kehandalan (reability) kualitas layanan TK X di Kabupaten Lumajang dinilai sangat puas

d. Harapan dan persepsi terhadap dimensi daya tanggap (responsiveness) kualitas layanan TK X di Kabupaten Lumajang dinilai sangat puas

e. Harapan dan persepsi terhadap dimensi jaminan (assurance) kualitas layanan TK X di Kabupaten Lumajang dinilai sangat puas

f. Harapan dan persepsi terhadap dimensi emphati (emphaty) kualitas layanan TK $\mathrm{X}$ di Kabupaten Lumajang dinilai sangat puas

\section{Saran}

Atas hasil penelitian dan pembahasan di atas, maka diberikan saran-saran kepada beberapa pihak sebagai berikut :

a. Bagi TK X Kabupaten Lumajang 
Kondisi persaingan di bidang jasa pendidikan mulai menampakkan suasana yang sangat ketat, kemudahan dalam kebijakan mendirikan sekolahan atau play group merupakan sebuah usaha pemerintah untuk membuat masyarakat mau untuk bersekolah diusa yang dini. Oleh karena itu dibutuhkan niai tambah oleh TK X untuk dapat berdaya saing diantara banyak sekolahan play group, seperti kolam renang yang menjadi nilai kepuasan tersebidir bagi wali murid, dan hendaknya menambahkan nilai tambah lainnya dibidang pelayanan dan fasilitas.

b. Bagi Petugas atau guru/ustadzah Sumber Daya Manusia

Pada bidang usaha jasa pendidikan, karyawan merupakan asset yang berharga untuk keberlangsungan usaha perusahaan. Kinerja karyawan berpengaruh terhadap kinerja perusahaan, sehingga karyawan yang menjadi roda pelayanan yang terjun langsung dalam operasional hendaknya diberikan pelatihan dan peilaian kinerja agar dapat terus meningkatkan kualitas pelayanan yang diberikan kepada wali murid dan juga memiliki tolak ukur kinerja yang baik dan sosok petugas yang ideal di TK X.

c. Bagi Penelitian Selanjutnya

Keterbatasan pada penelitian ini tidak lengkapnya identitas responden penelitian dan juga belum membahas mengenai hubungan antar variabel secara detail serta faktor-faktor yang mempengaruhi kepuasan pelanggan terhadap kualitas pelayanan TK X.

\section{DAFTAR RUJUKAN}

Anggraeni, Puspita.2015. Hubungan Antara Kualitas Pelayanan Dengan Kepuasan Konsumen Pada Mahasiswa Pengguna Game Pointblank. Yogyakarta; Universitash Ahmad Dahlan

Departemen Pendidikan Naional Republik Indonesia. Undang- Undang Republik Indonesia Nomor 20 tahun 2003. Biro Hukumdan Organisasi Sekertariat Jendral Depdiknas :Jakarta.

Engel, J.F., R.D, Blackwell., and P.W, Miniard, 1994. Perilaku Konsumen. Jakarta: Binarupa Aksara

Iqbal, Mohamad. 2008. PENGARUH PERSEPSI NILAI, HARAPAN, DAN KEPERCAYAAN TERHADAP KEPUASAN KONSUMEN PADA PENYEDIA JASA INTERNET DI JABODETABEK. Surabaya:Unniversitas Gunadarma

Shaleh, Abdul Rahman dan Wahab, Muhib Abdul . Psikologi Suatu Pengantar Perspektif dalam Islam. Jakarta: Kencana. 2004.

Sukoco dan Sengguruh Nilowardono.2009. Analisa harapa dan persepsi pelanggan PT. PLN (PERSERO) APJ Surabaya Utara. Surabaya:Universitas Narotama

Unzicker Deborah, K, (1999), "The Psychology of Being Put on Hold: An Exploratory Study of Service Quality", Psychology and Marketing; jul 1999; 16, 4; ProQuest Psychology Journals pg.327

UNICEF Indonesia. 2012. Ringkasan dan Kajian Pendidikan dan Perkembangan Anak Usia Dini. https://www.unicef.org/indonesia/id/A3 B Ringkasan Kajian Pendidikan.pdf 